\title{
Assessment of knowledge, attitude and practice about the menstruation among secondary school girls in Herat, Afghanistan - A cross sectional study
}

\section{Ahmad Neyazi}

Afghanistan Medical Students Association https://orcid.org/0000-0002-6181-6164

\section{Gulalai Faizi}

Kabul University of Medical Science

Habibah Afzali ( $\nabla$ habibahamidi1399@gmail.com )

Ghalib University

Mozhgan Ahmadi

Ghalib University

Nosaibah Razaqi

Khyber Girls Medical College

\section{Zahra Frough}

Herat University

\section{Sudip Bhattacharya}

Independent Public Health Researcher

\section{Research Article}

Keywords: Knowledge, Menstruation, Hygiene, Adolescent, Herat-Afghanistan

Posted Date: August 27th, 2021

DOl: https://doi.org/10.21203/rs.3.rs-847912/v1

License: (9) This work is licensed under a Creative Commons Attribution 4.0 International License. Read Full License 


\section{Abstract}

Background: The experience of menarche is often horrifying for adolescent girls due to their lack of information on menstruation cycle and menstrual vaginal bleeding. The aim of this study was to assess the knowledge and practice about menstruation and menstruation hygiene among secondary school girls in Herat, Afghanistan.

Methods: This cross-sectional study was conducted on $10^{\text {th }}$ March 2021 to $15^{\text {th }}$ April 2021 among secondary schools' girls in Herat, Afghanistan to evaluate the secondary school girls' knowledge on menstruation and menstruation hygiene. Sample size was calculated as $768 \mathrm{girls}$. Data were evaluated in IBM SPSS program.

Results: In this study $53.3 \%$ of girls a good knowledge on menstruation and menstruation hygiene. Only $15.9 \%$ of girls who did not experienced menarche at the time of this study, has a good knowledge score on menstruation and menstruation hygiene. $32.9 \%$ of the participants took rest and may missed their school during menstrual bleeding. Only $2.1 \%$ of the participants' first source of information on menstruation and menstruation hygiene was their teachers. The findings of the study show significant association between the fathers' educational level and girls' knowledge of menstruation and menstruation hygiene.

Conclusion: Girls knowledge on menstruations and menstruation hygiene was found to be lower than other countries. Awareness campaigns regarding the menstruation and menstruation hygiene are recommended to be conducted. However, it would be better to add a subject for secondary school girls so they can learn more and openly on this matter.

\section{Introduction}

With almost 1.2 billion people aged between 10 to 19 years old, adolescents form a large segment of the population across the world which is equivalent to $16 \%$ of the world's population (1). During adolescence, hormone activities which dawn with the hypothalamus secreting growth hormone and gonadotropin, cause changes both physically and emotionally and initiates pubertal changes in girls (2-3). This is why adolescence is marked as the onset of the first menstruation cycle which is called menarche (4).

During the menstruation cycle, the vaginal bleeding process happens periodically and continues a minimum of 2 days and a maximum of 7 days each month until menopause (5-6). In developing countries, the menstruation cycle is considered unclean, dirty, shameful, and embarrassing and this causes adolescent girls to become a vulnerable group across the world particularly in Afghanistan where a female child is a neglected child (7-9). Menstruation and menstruation hygiene has not been taken seriously in most of the developing countries (10). Poverty and low educational level on reproductive 
health are two of the major causes that affect the girls' knowledge and practice on menstruation and menstruation hygiene and her preparedness before experiencing the menarche (11).

The experience of menarche is often horrifying for adolescent girls due to their lack of information on the menstruation cycle and menstrual vaginal bleeding (12). Unfortunately, the lack of knowledge on practicing good menstruation hygiene is the other major problem that exists even among adolescent girls who passed the menarche which puts the girls' health at risk (13). In developing countries, many of the girls miss their classes due to poor menstrual hygiene management tools in schools during their menstrual bleeding (14).

One of the ways that help Afghanistan achieve the sustainable development goals (SDG) 3 - Good health and well-being (ensure healthy lives and well-being for all at all ages), SDG 4 - Quality education (ensure inclusive and equitable quality education and promote lifelong learning opportunities for all), SDG 5 - Gender equality (promote gender equality and empower all women and girls) and SDG 6 - Clean water and sanitation (ensure the availability and sustainable management of water and sanitation for all) is to improve the girls' awareness on menstruation and menstruation hygiene (15).

The aim of this study was to assess the knowledge, attitude, and practice about menstruation and menstruation hygiene among secondary school girls in Herat, Afghanistan.

\section{Materials And Methods}

This cross-sectional study was conducted from 10th March 2021 to 15th April 2021 among secondary school girls in Herat, Afghanistan.

Participants in this study were students of seventh to ninth-class schoolgirls living in Herat city of Afghanistan. Totally 768 secondary school girls participated in this research.

The questionnaire used for this study was developed based on a literature review. The questionnaire was designed and prepared in the Dari language. After conducting a pilot study among 30 school girls to check the readability and understanding of the questionnaire, minor changes in the format and design of the choices for questions were applied.

The final questionnaire consisted of three parts: The socio-demographic part which was designed to collect the participants' age, class, mother's educational level, father's educational level, mother's occupation, father's occupation, age at the time of menarche, and the first source of information on menstruation and menstruation hygiene. The second part consisted of seven questions to evaluate the participants' knowledge of menstruation and menstrual hygiene. Each question was scored 1 for the correct answer (total 7 scores). The ones with 4 scores or higher were considered to have a good knowledge level as it is the median score of the whole participants. The third section consisted of six questions to represent the participants' practice or attitude towards their menstruation and menstruation hygiene. 
The recorded data was entered into the IBM SPSS version 24.0 and the statistical analysis was done using this software. The simple random sampling method was used to determine the participants. A total of 768 participants studying in seventh to ninth class in different schools of Herat city participated in this study and filled the questionnaire. Variables of each part were presented in category form with their frequency in number and percentage.

Compute variable was used to calculate the total knowledge score of the participants. Cross tabulation was applied to evaluate the association between the participant's level of knowledge on menstruation and menstrual hygiene with their parents' educational level. A-value was considered as 0.05 .

\section{Ethical approval}

was obtained from the AMSA Medical Research Center Ethical Committee on 7th March 2021. Permission was secured from Herat Education Department or schools through a formal letter and orally. They were briefed on the relevance and objectives of the study. The purpose of the study was explained to each participant. Confidentiality of information was maintained by omitting any personal identifier from the questionnaire. Students were informed of their full right to continue or to ignore any question or even withdraw from their participation at any stage.

\section{Results}

The socio-demographic characteristics of the participants are presented in Table 1. Seven hundred sixtyeight participants were included in this research. $22.4 \%$ of the participants were in the seventh class, and $40.2 \%$ of the participants were in the eighth class. $52.2 \%$ of the participants' mothers were illiterate. And only $11.2 \%$ of the participants' mothers graduated high school. $17.2 \%$ of the participants' fathers were high school graduates and $24.9 \%$ of their fathers were graduated from university. $81.4 \%$ of the participants' mothers were busy with house jobs while $16.1 \%$ of the participants' fathers were unoccupied. $22.9 \%$ of the participants have not experienced menarche. $0.3 \%$ of the participants have experienced their menarche when they had 9 years old. $8.1 \%$ of the participants experienced their menarche when they had 14 years old. 
Table 1

Characteristics of participants

\begin{tabular}{|c|c|c|}
\hline Characteristic & Category & (\%) \\
\hline \multirow[t]{2}{*}{ Age group } & $11-14$ years old & 60.7 \\
\hline & $15-18$ years old & 39.3 \\
\hline \multirow[t]{3}{*}{ Class } & Seven & 22.4 \\
\hline & Eight & 40.2 \\
\hline & Nine & 37.4 \\
\hline \multirow[t]{5}{*}{ Mother's educational level } & Illiterate & 52.2 \\
\hline & Primary school & 10.9 \\
\hline & Secondary school & 13.8 \\
\hline & High school & 11.2 \\
\hline & University & 11.8 \\
\hline \multirow[t]{5}{*}{ Father's educational level } & Illiterate & 27.3 \\
\hline & Primary school & 13.0 \\
\hline & Secondary school & 17.6 \\
\hline & High school & 17.2 \\
\hline & University & 24.9 \\
\hline \multirow[t]{5}{*}{ Mother's occupation } & Permanent & 13.4 \\
\hline & Contract & 1.3 \\
\hline & House wife & 81.4 \\
\hline & Retired & .4 \\
\hline & Other & 3.5 \\
\hline \multirow[t]{6}{*}{ Father's occupation } & Permanent & 27.7 \\
\hline & Owner & 8.5 \\
\hline & Contract & 27.2 \\
\hline & Unoccupied & 16.2 \\
\hline & Retired & 1.0 \\
\hline & Other & 19.4 \\
\hline
\end{tabular}




\begin{tabular}{|lll|}
\hline Characteristic & Category & (\%) \\
\hline Age at the time of menarche & Did not experience & 22.9 \\
& Nine & .3 \\
& Ten & 3.1 \\
Eleven & 7.9 \\
Twelve & 28.0 \\
& Thirteen & 29.7 \\
& Fourteen & 8.1 \\
\hline
\end{tabular}

Participants' knowledge of the menstrual cycle and menstrual hygiene is presented in Table 2. Of all the participants in this study, $61.2 \%$ of them did answer that menstruation is a physiological process and $5.9 \%$ of them answered that menstruation is a pathological process. $64.8 \%$ of the participants answered that the source of menstrual blood is the Uterus. $8.1 \%$ of the participants answered that the menstrual blood source is the Stomach. $64.1 \%$ of the participants answered that the normal cycle length is 21 to 35 days. And $19.4 \%$ of them answered that the menstruation cycle will continue forever. The first source of information before or after the menarche for $56.5 \%$ of the participants was their mother. 
Table 2

Participants Knowledge on menstrual cycle

\begin{tabular}{|c|c|c|c|}
\hline Variables & Category & $\mathbf{N}$ & $(\%)$ \\
\hline \multirow[t]{3}{*}{ What is menstruation } & Physiological process & 470 & 61.2 \\
\hline & Pathological process & 45 & 5.9 \\
\hline & Don't know & 253 & 32.9 \\
\hline \multirow[t]{3}{*}{ Source of menstrual blood } & Uterus & 498 & 64.8 \\
\hline & Stomach & 62 & 8.1 \\
\hline & Don't know & 208 & 27.1 \\
\hline \multirow[t]{3}{*}{ Normal cycle length } & $21-35$ days & 492 & 64.1 \\
\hline & More than 35 days & 40 & 5.2 \\
\hline & Don't know & 236 & 30.7 \\
\hline \multirow[t]{4}{*}{ Normal cycle bleeding length } & Less than 2 days & 53 & 6.9 \\
\hline & $2-7$ days & 421 & 54.8 \\
\hline & More than 7 days & 118 & 15.4 \\
\hline & Don't know & 176 & 22.9 \\
\hline \multirow[t]{3}{*}{ Will the period continue forever } & Yes & 149 & 19.4 \\
\hline & No & 462 & 60.2 \\
\hline & Don't know & 157 & 20.4 \\
\hline \multirow[t]{3}{*}{ Healthy diet during menstrual cycle exits } & Yes & 495 & 64.5 \\
\hline & No & 141 & 18.4 \\
\hline & Don't know & 132 & 17.2 \\
\hline \multirow[t]{2}{*}{ Ever hear about menstruation before menarche } & Yes & 301 & 39.2 \\
\hline & No & 467 & 60.8 \\
\hline \multirow[t]{6}{*}{ Source of information } & Mother & 434 & 56.5 \\
\hline & Sister & 154 & 20.1 \\
\hline & Friends & 12 & 1.6 \\
\hline & Ancestors & 8 & 1.0 \\
\hline & Teacher & 16 & 2.1 \\
\hline & No one & 144 & 18.8 \\
\hline
\end{tabular}




\begin{tabular}{|llll|}
\hline Variables & Category & N & (\%) \\
\hline Knowledge score (Girls who passed menarche) & Good & 381 & 64.4 \\
& Poor & 211 & 35.6 \\
\hline Knowledge score (girls who did not pass menarche) & Good & 28 & 15.9 \\
& Poor & 148 & 84.1 \\
\hline Overall Knowledge score & Good & 409 & 53.3 \\
& Poor & 359 & 46.7 \\
\hline
\end{tabular}

Participants' practice during menstruation is presented in Table 3. Of all the participants, $36.7 \%$ of them mostly felt pain during their period. $9.0 \%$ of the participants used an OTC pain reliever to relieve their pain during their menstruation. $10.4 \%$ of the participants exercise to relieve the menstruation bleeding pain. $61.1 \%$ of the participants preferred to use Pads to manage and absorb the menstrual discharge. $60 \%$ of the participants preferred using the absorption materials of menstrual discharge for less than 4 hours. $53.6 \%$ of the participants mostly sanitize the absorption materials of menstrual discharge. 
Table 3

Participants attitude and practice during menstruation

\begin{tabular}{|c|c|c|c|}
\hline Variables & Category & $\mathbf{N}$ & (\%) \\
\hline \multirow[t]{4}{*}{ Feeling pain during period } & Mostly & 282 & 36.7 \\
\hline & Rarely & 215 & 27.0 \\
\hline & Never & 123 & 16.0 \\
\hline & No response & 148 & 19.3 \\
\hline \multirow{6}{*}{$\begin{array}{l}\text { Things you do during menstrual bleeding to relief period pain and } \\
\text { its effects }\end{array}$} & Exercise & 80 & 10.4 \\
\hline & Use heating pad & 94 & 12.2 \\
\hline & OTC pain reliever & 69 & 9.0 \\
\hline & Rest & 253 & 32.9 \\
\hline & Other & 108 & 14.1 \\
\hline & No response & 164 & 21.4 \\
\hline \multirow[t]{5}{*}{ Materials use for absorption of menstrual discharge } & Pads & 469 & 61.1 \\
\hline & Cloths & 66 & 8.6 \\
\hline & Both & 82 & 10.7 \\
\hline & Other & 7 & 0.9 \\
\hline & No response & 144 & 18.8 \\
\hline \multirow[t]{5}{*}{ Length of usage of absorption materials of menstrual discharge } & Less than 4 & 466 & 60.7 \\
\hline & 4-6 hours & 97 & 12.6 \\
\hline & More than 12 & 41 & 5.3 \\
\hline & hours & 164 & 21.4 \\
\hline & No response & & \\
\hline \multirow[t]{4}{*}{ Sanitize menstruation discharge absorption materials } & Mostly & 412 & 53.6 \\
\hline & Rarely & 124 & 16.1 \\
\hline & Never & 92 & 12.0 \\
\hline & No response & 140 & 18.2 \\
\hline \multirow[t]{3}{*}{ Do you wash yourself during menstrual bleeding } & Yes & 325 & 42.3 \\
\hline & No & 303 & 39.5 \\
\hline & No response & 140 & 18.2 \\
\hline
\end{tabular}


The association between participants' knowledge of menstruation and their mother's educational level is shown in Table 4. 58.2\% of the participants' knowledge on menstruation and menstruation hygiene whose mother had college or higher educational level was found to be good.

Table 4

Association between participants' knowledge of menstruation and their mother's educational level

\begin{tabular}{|llll|}
\hline Mother's educational level & Category & N & (\%) \\
\hline Illiterate & Good & 218 & 54.4 \\
& Poor & 183 & 45.6 \\
Primary school & Good & 37 & 44.0 \\
Secondary school & Poor & 47 & 56.0 \\
\hline High school & Good & 58 & 54.7 \\
& Poor & 48 & 45.3 \\
\hline \multirow{2}{*}{ College } & Good & 43 & 50.0 \\
& Poor & 43 & 50.0 \\
\hline
\end{tabular}

P-value $=0.352$

Association of the participants' knowledge on menstruation and their father's educational level is presented in Table 5. 46.7\% of Participants with illiterate fathers had good knowledge on menstruation and menstruation hygiene. $63.4 \%$ of participants with their father's educational level of college or higher had good knowledge on menstruation and menstruation hygiene. 
Table 5

Association between participants' knowledge of menstruation and their father's educational level

\begin{tabular}{|llll|}
\hline Father's educational level & Category & N & (\%) \\
\hline Illiterate & Good & 98 & 46.7 \\
& Poor & 112 & 53.3 \\
\hline Primary school & Good & 51 & 51.0 \\
& Poor & 49 & 49.0 \\
\hline Secondary school & Good & 60 & 44.4 \\
High school & Poor & 75 & 55.6 \\
& Good & 79 & 59.8 \\
\hline College & Poor & 53 & 40.2 \\
& Good & 121 & 63.4 \\
\hline
\end{tabular}

P-value $=0.001$

\section{Discussion}

Menstruation is a normal physiological process in females that is a part of pubertal development (16, 17). In this cross-sectional study among secondary school girls in Herat city, only $39.2 \%$ of the participants heard about menstruation before they experience menarche. A study by Funmito Omolola Fehintola et, al. among secondary school girls in Nigeria showed that $96.4 \%$ of girls heard about menstruation before experiencing menarche (17). In another related study by Shivaleela P. Upashe et, al. in Western Ethiopia, 79.3\% of girls heard about menstruation before menarche while Teketo Kassaw Tegegne et, al. study result shows that $86.7 \%$ of girls in Northeast Ethiopia heard about menstruation and menstruation hygiene before menarche $(18,19)$. In the general population to be polite, no one takes the name of genital systems parts, although it is part of the human body's it would be considered as impoliteness. According to this study result, most of the girls do not know anything about menstruation when they experience menarche. This makes the menarche a bad and fearful experience for them.

In general, $53.3 \%$ of the participants of this study had a good knowledge level on menstruation and menstruation hygiene. While $81.4 \%$ of the participants who did not experience menarche had poor knowledge of menstruation and menstruation hygiene. This study also shows that $35.6 \%$ of the girls who experienced menarche had poor knowledge of menstruation and menstruation hygiene. Although $38.8 \%$ of the participants did not know that menstruation is a physiological process of the female body and $35.2 \%$ of them did not know that the source of blood in the menstrual cycle is the uterus. The study by Teketo Kassaw Tegegn et, al. showed that $51.4 \%$ of schoolgirls in Northeast Ethiopia had a good 
knowledge score on menstruation hygiene. Another study by Hussein Mohammed Gena in Eastern Ethiopia shows that $58.3 \%$ of schoolgirls had a good practice score on menstruation and menstruation hygiene $(19,20)$. Low level of knowledge of parents, thinking of menstruation as a shame are considered the main causes of the lower level of knowledge among girls. However, considering other country's girls' knowledge scores on menstruation and menstruation hygiene, the knowledge score of the girls in this study who did not experience menstruation is surprisingly bad.

Almost one-third (32.9\%) of the participants replayed that they take rest and may not even attend school during menstrual bleeding. Compared to a study by George Miiro et, al. that shows $20 \%$ of schoolgirls miss at least one day of their school during menstrual bleeding and another study by Aditi Vashisht et, al. shows that $40 \%$ of school girls missed their school during their last period. Our finding was almost in line with the study by Aditi Vashisht et, al. in Indian, in missing schools during menstruation. The reason for this match could be sharing the same beliefs and myths about menstruation among the general population of Afghanistan and India $(21,22)$. According to studies missing school is due to a lack of menstruation hygiene management instruments and toilets $(23-30)$.

Mothers' educational level association with girl's menstruation knowledge score was not found significant in this study. Mothers' educational level association with girl's menstruation knowledge score was not significant. However, in families with a father's higher educational level, a girl's knowledge score on menstruation was found to be significant. Considering only $2.1 \%$ of the participants of this study's primary source of information was teachers, it can be one of the reasons why the association between mothers' educational level and girl's knowledge score on menstruation is not significant. This shows the lack of awareness campaigns on the need to talk about menstruation in schools.

\section{Conclusion}

Only half of the participants had good knowledge of menstruation and menstruation hygiene. Which is not an encouraging sign at all. Our research finding shows, the association of good knowledge on menstruation and menstruation hygiene with their parents. Awareness campaigns/counselling sessions in the schools regarding the menstruation and menstruation hygiene are recommended to be conducted involving their parents. However, it would be better to add a subject regarding menstrual hygiene in the curriculum for secondary school girls so they can learn more and discuss openly on this matter.

\section{Declarations}

\section{Author contributions}

All authors made substantial contribution to conception and design, data collection and data entry, data analysis and their interpretation, drafting the article and giving the finale approval of the version to be published, and agreed to be accountable for all aspects of work. 
Acknowledgements: We would like to acknowledge the participants who cooperated with the data collection process.

Funding: No external fund was received for this study.

Competing interests: None declared.

\section{References}

1. Adolescent Demographics - UNICEF DATA [Internet]. UNICEF DATA. 2021 [cited 2 May 2021]. Available from: https://data.unicef.org/topic/adolescents/demographics/

2. Sisk CL, Foster DL. The neural basis of puberty and adolescence. Nature neuroscience. 2004 Oct, $7(10): 1040-7$.

3. Vijayakumar N, Pfeifer JH, Flournoy JC, Hernandez LM, Dapretto M. Affective reactivity during adolescence: Associations with age, puberty and testosterone. Cortex. 2019 Aug 1;117:336 - 50.

4. Viner RM, Allen NB, Patton GC. Puberty, Developmental Processes, and Health Interventions.

5. Anwar S, Al Jahwari JA, Al Kharousi MN, Al Adawi AH, Samad RA, Al-Zubaidi N. Knowledge and Practices of Omani Adolescent Girls Related to Menstruation.

6. Ganong WF. Review of medical physiology. Mcgraw-hill; 1995 Apr.

7. Why Afghanistan Is Still the Worst Place in the World to Be a Woman [Internet]. Time. 2021 [cited 2 May 2021]. Available from: https://time.com/5472411/afghanistan-women-justice-war/

8. Dasgupta A, Sarkar M. Menstrual hygiene: how hygienic is the adolescent girl?. Indian journal of community medicine: official publication of Indian Association of Preventive \& Social Medicine. 2008 Apr,33(2): 77.

9. Montgomery P, Hennegan J, Dolan C, Wu M, Steinfield L, Scott L. Menstruation and the cycle of poverty: a cluster quasi-randomised control trial of sanitary pad and puberty education provision in Uganda. Plos one. 2016 Dec 21;11(12):e0166122.

10. Menstruation and human rights - Frequently asked questions [Internet]. Unfpa.org. 2021 [cited 2 May 2021]. Available from: https://www.unfpa.org/menstruationfaq

11. Changing the Cycle: Period Poverty as a Public Health Crisis [Internet]. Sph.umich.edu. 2021 [cited 2 May 2021]. Available from: https://sph.umich.edu/pursuit/2020posts/period-poverty.html

12. Gupta J, Gupta H. Adolescents and menstruation. Journal of Family Welfare. 2001;47(1):1-3.

13. Alharbi KK, Alkharan AA, Abukhamseen DA, Altassan MA, Alzahrani W, Fayed A. Knowledge, readiness, and myths about menstruation among students at the Princess Noura University. Journal of family medicine and primary care. 2018 Nov;7(6):1197.

14. Davis J, Macintyre A, Odagiri M, Suriastini W, Cordova A, Huggett C, Agius PA, Budiyani AE, Quillet C, Cronin AA, Diah NM. Menstrual hygiene management and school absenteeism among adolescent students in Indonesia: evidence from a cross-sectional school-based survey. Tropical Medicine \& International Health. 2018 Dec;23(12):1350-63. 
15. THE 17 GOALS | Sustainable Development [Internet]. Sdgs.un.org. 2021 [cited 2 May 2021]. Available from: https://sdgs.un.org/goals

16. Critchley HO, Maybin JA, Armstrong GM, Williams AR. Physiology of the endometrium and regulation of menstruation. Physiological reviews. 2020 Jul 1;100(3):1149-79.

17. Fehintola FO, Fehintola AO, Aremu AO, Idowu A, Ogunlaja OA, Ogunlaja IP. Assessment of knowledge, attitude and practice about menstruation and menstrual hygiene among secondary high school girls in Ogbomoso, Oyo state, Nigeria. International Journal of Reproduction, Contraception, Obstetrics and Gynecology. 2017 May;6(5):1726-32.

18. Upashe SP, Tekelab T, Mekonnen J. Assessment of knowledge and practice of menstrual hygiene among high school girls in Western Ethiopia. BMC women's health. 2015 Dec,15(1):1-8.

19. Tegegne TK, Sisay MM. Menstrual hygiene management and school absenteeism among female adolescent students in Northeast Ethiopia. BMC public health. 2014 Dec,14(1):1-4.

20. Mohammed Gena H. Menstrual Hygiene Management Practices and Associated Factors among Secondary School Girls in East Hararghe Zone, Eastern Ethiopia. Advances in Public Health. 2020 Nov 16,2020.

21. Miiro G, Rutakumwa R, Nakiyingi-Miiro J, Nakuya K, Musoke S, Namakula J, Francis S, Torondel B, Gibson LJ, Ross DA, Weiss HA. Menstrual health and school absenteeism among adolescent girls in Uganda (MENISCUS): a feasibility study. BMC women's health. 2018 Dec;18(1):1-3.

22. Vashisht A, Pathak R, Agarwalla R, Patavegar BN, Panda M. School absenteeism during menstruation amongst adolescent girls in Delhi, India. Journal of family \& community medicine. 2018 Sep;25(3): 163.

23. Alam MU, Luby SP, Halder AK, Islam K, Opel A, Shoab AK, Ghosh PK, Rahman M, Mahon T, Unicomb L. Menstrual hygiene management among Bangladeshi adolescent schoolgirls and risk factors affecting school absence: results from a cross-sectional survey. BMJ open. $2017 \mathrm{Jul}$ 1;7(7):e015508.

24. Davis J, Macintyre A, Odagiri M, Suriastini W, Cordova A, Huggett C, Agius PA, Budiyani AE, Quillet C, Cronin AA, Diah NM. Menstrual hygiene management and school absenteeism among adolescent students in Indonesia: evidence from a cross-sectional school-based survey. Tropical Medicine \& International Health. 2018 Dec;23(12):1350-63.

25. Van Eijk AM, Sivakami M, Thakkar MB, Bauman A, Laserson KF, Coates S, Phillips-Howard PA. Menstrual hygiene management among adolescent girls in India: a systematic review and metaanalysis. BMJ open. 2016 Mar 1;6(3).

26. Benshaul-Tolonen A, Zulaika G, Sommer M, Phillips-Howard PA. Measuring Menstruation-Related Absenteeism Among Adolescents in Low-Income Countries. The Palgrave Handbook of Critical Menstruation Studies. 2020:705 - 23.

27. Phillips-Howard PA, Caruso B, Torondel B, Zulaika G, Sahin M, Sommer M. Menstrual hygiene management among adolescent schoolgirls in low-and middle-income countries: research priorities. Global health action. 2016 Dec 1;9(1):33032. 
28. Sommer M, Sahin M. Overcoming the taboo: advancing the global agenda for menstrual hygiene management for schoolgirls. American journal of public health. 2013 Sep;103(9):1556-9.

29. Hennegan J, Dolan C, Wu M, Scott L, Montgomery P. Measuring the prevalence and impact of poor menstrual hygiene management: a quantitative survey of schoolgirls in rural Uganda. BMJ open. 2016 Dec 1;6(12).

30. Bhattacharya S, Singh A. How effective is the Menstrual Hygiene Scheme? An evaluation study from North India. Int J Community Med Public Health. 2016 Sep;3(9):2584-2586. 